Katarzyna Krasoń, Jolanta Bonar, Joanna Garbula, Elżbieta Jaszczyszyn,

Agnieszka Nowak-Łojewska, Małgorzata Łączyk, Iwona Kopaczyńska, Agnieszka Olczak, Aleksandra Różańska, Anna Tyl

Poland

\title{
Dimorphic Outlook on Children's Creative Attitudes on the Verge of Education Application of Creative and Re-constructive Attitudes Rating Scale (SPTO)
}

DOI: 10.15804/tner.2015.42.4.24

\begin{abstract}
This study has been devoted to creative attitudes represented by 6-7-year old children, evaluated by the creative and re-constructive attitudes rating scale (SPTO $)^{1}$. The central focus was to relate differences in attitudes among children commencing their education at the age of 6 to those who had started their school attendance before the reform (at the age of 7). An attempt was made to answer the question whether pupils differing in the year of birth, joined within one school form, would generate any disruption of their potential creativity. A complementary issue was to evaluate the level of creative attitudes along the dimorphic pattern.
\end{abstract}

Keywords: creative attitude, diagnosis, school threshold lowering

\section{Introduction}

Assessment of the lowered primary school threshold, so widely commented on across different milieus not necessarily involved in education, makes us state

1 The study was conducted within the framework of the Elementary Education Group, under the auspices of the Committee for Pedagogical Studies, Polish Academy of Sciences. 
explicitly that numerous arguments for or against lowering must evoke some mixed feelings. It is not our objective, however, to suggest any solutions, but rather to indicate certain regularities in shaping of a child's creative attitude, revealed when accepting certain functional strategies, divergent or, on the contrary, conformist one, which determine the approach towards homework and success achieved when taking up the school challenges.

The issue appears of utmost importance, as actualization of the creative potential, therefore a creative attitude towards the task are among the key competences indispensable for the contemporary citizen to perform in the continuously changing reality (Bauman Z., 2007). It should be emphasized that children need a creative inclination to explore the world, as the need is a primary one, necessary for the optimum development of a human being throughout the growth period of self-creation (Trojanowska-Kaczmarska A., 1971, p. 57). Here, we arrive at the traits that need to be shaped during the educational process. In this context, it is worth generalizing some creative predispositions, as proposed by Marian Golka, who took into consideration the following primary attributes: intelligence, extensive knowledge, independence, courage, reluctance to authorities, aloofness from achievements of science, concentration skills, persistence in interests, flexible thinking, imagination, penchant for fantasizing or ability to marvel at the world. The latter is particularly valuable, making it possible to generate the pupil's open-mindedness and curiosity about the world, which should occur in line with recognition of "the wide range of stimuli available for an individual associated with emotions, desires and thoughts" (Zborowski J., 1986, p. 26), in other words, a desire to launch a rich variety of experience, as postulated by Jan Zborowski. Moreover, the emotional layer is a rudimentary one, as a first-former must feel safe and has to experience positive emotions when discovering the world. One should not underestimate resistance to failure encountered upon such exploration/education. Are the youngest pupils ready to take up challenges, risking some unsuccessful attempts and will they be able to cope with such emotions? We will try to answer this question further on.

However, let us first define some terms, placing the notion of the creative attitude in the pedagogical context. For the purpose of this study, we assumed that an attitude is the effect, or rather, result of beliefs, emotions and behaviours (Wojciszke B., 2002). Beliefs result in an emotional attitude towards an object resulting from conscious valuation (recognition of advantages and disadvantages). "An attitude is a go-between linking past and future experience with a given object and may be determined with emotions experienced so far in relation to the object (...) an attitude influences later emotional response to the object, opinions and decisions as well as 
actions taken with regard to the object" (Bernacka R. E., 2004, p. 74). The tools to evaluate such attitudes are based upon recognition of some specific approach (long-term experience), interests, motivation as well as style of performance.

It should not be different when creative attitudes are objects of our investigation. We assume that a creative attitude is a predisposition "to create, which potentially exists in all humans at any age" (Gloton R., Clero C., 1985, p. 49), determined by the environment, i.e. the social and cultural surroundings in which one grows up.

In such a context, the major issue is to look for relevant diagnostic patterns to evaluate the creative attitude of a child just beginning its school education. It is essential, then, to accept the specific nature of the subject of the study. As application of the "adult" rules to assess a child's creations is a major mistake (Kubicka D., 2003, p. 60). The diagnosis of an approach to creation or a creative attitude requires a specific outlook as well as specific exploration methods. The available questionnaires $^{2}$ accept basically the self-estimation pattern to enable a diagnosis of creative predispositions "thanks to information on an individual's perception of the world, other people and himself” (Nęcka E., 2001, p. 194). They assume no creative tasks, unfortunately based on one's ability to make accurate and generalized opinions about oneself - personal interests, likes and ways of behaviour, which for a few year old child may appear a challenge difficult to face. It would be hard, then, to speak of sophisticated knowledge of oneself, self-reflection or verbal conceptualization ability; therefore the questionnaires are usually dedicated to educated adults. It may also appear unfortunate to recognize the tendency to present oneself in a better light, just to be appreciated by the examiner. D. Kubicka emphasizes, however, that it may have a positive measure, informing about creativity from the subject's perspective (Kubicka D., 2005).

It should be indicated that the evaluation of form 1-3 pupils requires highly precise instructions, tailored to the developmental level of the early school age, while any tasks given must also be specially expressed, preferably in the form of icons or verbally, both, however, referring to the child's interests and experience. Further on we are going to present a tool, in our opinion, helpful to penetrate the specific attitudes of a small child.

2 Cf.: How do You Think (HDYT) Gary A. Davis; The Adjective Check List - Creative Personality Scale, Harrison G. Gough and Alfred B. Heilbrun; KANH Creative Behaviour Questionnaire by S. Popek; Creative Behaviour Style Questionnaire by A. Strzałecki. 


\section{SPTO3 tool - brief characteristics}

The scale contains some accurately designed scenes - diagnostic situations rooted in the nearest environment of form 1-3 pupils, referring to their past experience or perceived earlier reality. Based on the dichotomy choice of one strategy, out of the two presented ones, it points to preferences of the evaluated individual. It has been our intention not to make choices in the dimorphic way, therefore we are not comparing the girls' and the boys' strategies upon a single story to avoid any stereotypical selection (which cannot be excluded at the early school age). To make a task precise, it is presented in the iconic manner, including a description, most of the message, however, is based on drawings, exemplifying the selection options. This has been done on purpose, following the visual presentation schemes as well as coding redundancies when working with a child whose thinking levels have only started to turn towards some abstract categories. The concrete terms are needed for a diagnostic situation, while the pictures reflect precisely the scope of choices the child is supposed to make. The way of solving the problem is explained in the introduction addressed to the pupils, telling them to mark one of the squares with a letter, corresponding to the story he/she likes best and in which he/she would act in the same manner. It is essential to emphasize that there are no "good" or "wrong" answers and that any choice is correct, provided it is accepted by the child.

The tool has been designed to incorporate several parts within two modules: module I - identification and module II - self-assessment. In module one, choices are made from the observer's viewpoint and facilitate the task through concrete identification with the character. Then, the choice of a strategy should be made, at least to a certain extent, from another person's perspective, as a few year old child may find it difficult to recognize the so-called personal perspective and if employing the I relation tends to reply in the way the person asking a question would expect. Here, he/she assesses the strategy him/herself, not him/herself within the strategy. To sum up, a pupil makes his/her choices through identification with the character of the scene, preventing therefore a problem associated with self-estimation, where the focus is shifted towards selection of a strategy rather than self-reflection.

3 The rating scale is published along with the Manual, cf. K. Krason (2011). The manual, including the test, has been developed within the project by Andrzej Frycz Modrzewski Academy, Cracow, co-financed by the EU - European Social Fund "Human Capital. National Cohesion Strategy". 
Module I is divided into 4 parts:

1) determining divergence;

2) referring to motivation ${ }^{5}$;

3) showing a tendency to extensive elaboration of new behaviours ${ }^{6}$;

4) revealing attitudes towards failure in creative activities ${ }^{7}$.

Module II - self-estimating one - is a sub-scale also based upon a dichotomy choice, however referring to self-knowledge, assuming that module I has already shaped readiness to evaluate a strategy, now easier referred to self-reflection. This module brings up the major issues of coping with difficulties (difficult situation), from an interpersonal outlook, when a situation is evaluated "in the company" of

${ }^{4}$ Evaluation of divergence focused on diagnosis of readiness to search for one's own, original solutions, where divergence is understood as a tendency to a high level of thinking flexibility and novelty with no reference to ready solutions and the algorithm assumed as an inclination to apply the known solution as well as those given by others.

The 4 stories given followed the pattern - from the most obvious one (Treasure Hunt), which clearly distinguishes between "easy", "straightforward" strategies and procedures based upon one's own effort. Story 2 (Island) follows the same scheme. Story 3 (Helping in the school garden) shows a different measure, where the ways of behavior point to the need of some effort, however in real terms, the most frequent strategy taken up by children at this age is to seek the assistance of adults. The choice is then not so explicit. Finally, story 4 (Gift) is a task to be considered basically in individual terms (i.e. when a teacher evaluates his form with the purpose of an internal diagnosis of the team or its individual members). The choice here is even more difficult, as both solutions seem attractive; moreover there is a question of which choice the person given a gift will like best.

5 This part provides a diagnosis of the motivation sphere, i.e. it indicates whether a pupil assessed is driven by the care of his/her own image of an original individual or rather prefers not to stand out and to obey the rules; it also defines the reasons for creative activities - for one's own sake or for others. Therefore, the choice is between a story supposed to bring satisfaction to the writer exclusively (it has to be liked by him/her or be considered to be the best) or one to bring joy to the addressee.

6 Part 3 diagnoses the inclination to extensive elaboration of new activities and is supposed to evaluate orientation towards detailed activities, association with the number of elements of a situation perceived or superficial outlook on new reality.

7 Part 4 refers to coping with a difficult situation, appearing as criticism of the undertaken creative activity. In this case, some withdrawal strategies are possible, where criticism blocks the creative activities in more sensitive pupils or the task-based ones, where criticism is used as "a statement" to improve the solutions. The value of this part is worth mentioning. The replies given by pupils should ensure important information for the teacher to tailor his impact during the lesson to match the child's needs. We need to be aware that criticism of a pupil, who declares (by identification) a flight into withdrawal strategies after failure, will ultimately block him/her. The story also shows those who will develop better if appreciated in a constructive manner, even when imperfections are pinpointed. 
other people (I prefer to work with my mate or I like to be assessed by others), to an intra-personal one, preferring individual activities, however focused only on oneself (mainly 8.4). In this way, choices of what is liked or disliked upon creative tasks are indicated.

\section{Study report}

The enforced reform of elementary education assumed the shift of the school age from seven down to six. It appeared interesting, then, to compare the level of creative attitudes in the group of seven-year-old pupils, learning in the same form. The presented study focused on this issue ${ }^{8}$. The study comprised children from different regions of the country, with the distribution by age and sex criteria presented below:

Table 1. Age and sex of respondents

\begin{tabular}{|c|c|c|c|c|c|c|}
\hline \multirow{3}{*}{ Sex } & \multicolumn{4}{|c|}{ Child's age } & \multirow{2}{*}{\multicolumn{2}{|c|}{ Total }} \\
\hline & \multicolumn{2}{|c|}{6 years } & \multicolumn{2}{|c|}{7 years } & & \\
\hline & $\mathbf{n}$ & $\%$ & $\mathbf{n}$ & $\%$ & $\mathrm{n}$ & $\%$ \\
\hline Girls & 74 & 15.1 & 168 & 34.3 & 242 & 49.4 \\
\hline Boys & 82 & 16.7 & 166 & 33.9 & 248 & 50.6 \\
\hline Total & 156 & 31.8 & 334 & 68.2 & 490 & 100.0 \\
\hline
\end{tabular}

Source: own study.

The fundamental component of our considerations was comparing differences in the levels of creative attitudes among children starting their school education at the age of 6 to those whose learning at school started before the reform, when they were seven. It was attempted to answer the question whether combining pupils of different years of birth in one form would generate any disruption resulting from different levels of actualization of their creative potential. Moreover, a dimorphic criterion was introduced to verify whether the approach to creative tasks was manifested to a higher degree in girls or in boys.

Let us start with some differences revealed for 6- and 7-year-old girls (Table 2).

8 The study comprised children from different areas of Poland: Podlasie, śląskie region, Mazowsze and lubuskie region to provide a sample of 490 children in total (200 from small towns and villages and 290 from medium size and large cities). 
Table 2. Results of SPTO rating scale among the group of girls

\begin{tabular}{|c|c|c|c|c|c|}
\hline \multicolumn{6}{|c|}{ Results for girls } \\
\hline \multirow{2}{*}{ Rating scale } & \multirow{2}{*}{ age } & \multirow{2}{*}{$\mathbf{M}$} & \multirow{2}{*}{ SD } & \multicolumn{2}{|c|}{ U Mann-Whitney test } \\
\hline & & & & Average rank & Test parameters \\
\hline \multirow{2}{*}{$\begin{array}{l}\text { Module I } \\
\text { divergence aspect }\end{array}$} & 6.0 & 1.39 & 1.02 & 112.41 & \multirow{2}{*}{$\begin{array}{l}U=5543.0 ; Z=-1.403 \\
p<0.161\end{array}$} \\
\hline & 7.0 & 1.61 & 1.05 & 125.51 & \\
\hline \multirow{2}{*}{$\begin{array}{l}\text { Module I } \\
\text { motivation aspect }\end{array}$} & 6.0 & 2.04 & 0.96 & 129.18 & \multirow{2}{*}{$\begin{array}{l}U=5647.5 ; Z=-1.235 \\
p<0.217\end{array}$} \\
\hline & 7.0 & 1.86 & 0.85 & 118.12 & \\
\hline \multirow[t]{2}{*}{ Module I identification } & 6.0 & 4.66 & 1.68 & 109.03 & \multirow{2}{*}{$\begin{array}{l}U=5293.0 ; Z=-1.876 \\
p<0.061^{\star}\end{array}$} \\
\hline & 7.0 & 5.07 & 1.56 & 126.99 & \\
\hline \multirow[t]{2}{*}{ Module II interpersonal aspect } & 6.0 & 2.36 & 1.16 & 104.85 & \multirow{2}{*}{$\begin{array}{l}U=4984.0 ; Z=-2.561 \\
p<0.010\end{array}$} \\
\hline & 7.0 & 2.78 & 1.02 & 128.83 & \\
\hline \multirow[t]{2}{*}{ Module II intrapersonal aspect } & 6.0 & 1.16 & 0.74 & 104.91 & \multirow{2}{*}{$\begin{array}{l}U=4988.0 ; Z=-2.654 \\
p<0.008\end{array}$} \\
\hline & 7.0 & 1.43 & 0.79 & 128.81 & \\
\hline \multirow[t]{2}{*}{ Module II self-assessment } & 6.0 & 3.63 & 1.53 & 99.76 & \multirow{2}{*}{$\begin{array}{l}U=4607.5 ; Z=-3.284 \\
p<0.001\end{array}$} \\
\hline & 7.0 & 4.29 & 1.31 & 131.07 & \\
\hline \multirow[t]{2}{*}{ Creative attitude } & 6.0 & 8.29 & 2.57 & 103.95 & \multirow{2}{*}{$\begin{array}{l}U=4917.0 ; Z=-2.613 \\
p<0.009\end{array}$} \\
\hline & 7.0 & 9.37 & 2.18 & 129.23 & \\
\hline
\end{tabular}

Source: own study

The results in module I (identification), regarding divergence and motivation, show no differences between 6- and 7-year-old girls. Nevertheless, the evaluation performed along the whole module scale showed results within the statistical tendency limits. Statistical significance was within the range $\mathrm{p}>0.05$ and $\mathrm{p}<0.1$.

The results in module II (self-assessment), in the interpersonal and intra-personal aspect as well as the generalized view of all the components constituting the creative attitude measure, was statistically significant. This indicates differentiation between the 6- and 7-year-old girls. In all the sub-scales, the scores obtained by the seven-year-olds were higher than those obtained by the younger girls. Evidently, seven-year-olds better cope with difficulties and are more resistant to criticism. Although such differentiation is not visible in the area of divergent solutions, alterations appear in the sphere of specific maturity to face the learning challenges. Six-year-old girls may prove sensitive to failure, which may in consequence hamper their creative activities.

This supports the opinions frequently expressed by those who were critical of the lowered school threshold and although six-year-olds will undoubtedly cope 
with the curriculum their cognitive competence does not correspond to the emotional resistance of seven-year-olds. Indeed, this very aspect is a key factor of the generally understood creative attitude of a child.

Let us now consider the values scored by the boys in the same categories (Table 3).

Table 3. Results of SPTO rating scale among the group of boys

\begin{tabular}{|c|c|c|c|c|c|}
\hline \multicolumn{6}{|c|}{ Results for boys } \\
\hline \multirow{2}{*}{ Rating scale } & \multirow{2}{*}{ age } & \multirow{2}{*}{ M } & \multirow{2}{*}{ SD } & \multicolumn{2}{|c|}{ Non-parametric test } \\
\hline & & & & Average rank & Test parameters \\
\hline \multirow{2}{*}{$\begin{array}{l}\text { Module I } \\
\text { divergence aspect }\end{array}$} & 6.0 & 2.07 & 1.36 & 141.23 & \multirow{2}{*}{$\begin{array}{l}U=5434.5 ; Z=-2.702 \\
p<0.007\end{array}$} \\
\hline & 7.0 & 1.60 & 0.95 & 116.24 & \\
\hline \multirow{2}{*}{$\begin{array}{l}\text { Module I } \\
\text { motivation aspect }\end{array}$} & 6.0 & 1.48 & 0.91 & 100.9 & \multirow{2}{*}{$\begin{array}{l}U=4871.0 ; Z=-3.952 \\
p<0.000\end{array}$} \\
\hline & 7.0 & 1.92 & 0.73 & 136.16 & \\
\hline \multirow[t]{2}{*}{ Module I identification } & 6.0 & 4.46 & 1.28 & 106.16 & \multirow{2}{*}{$\begin{array}{l}U=5302.0 ; Z=-2.929 \\
p<0.003\end{array}$} \\
\hline & 7.0 & 5.02 & 1.28 & 133.56 & \\
\hline \multirow{2}{*}{$\begin{array}{l}\text { Module II interpersonal } \\
\text { aspect }\end{array}$} & 6.0 & 1.98 & 1.14 & 101.03 & \multirow{2}{*}{$\begin{array}{l}U=4881.5 ; Z=-3.743 \\
p<0.000\end{array}$} \\
\hline & 7.0 & 2.56 & 1.06 & 136.09 & \\
\hline \multirow{2}{*}{$\begin{array}{l}\text { Module II intra-personal } \\
\text { aspect }\end{array}$} & 6.0 & 1.15 & 0.80 & 111.96 & \multirow{2}{*}{$\begin{array}{l}U=5778.0 ; Z=-2.088 \\
p<0.037\end{array}$} \\
\hline & 7.0 & 1.37 & 0.76 & 130.69 & \\
\hline \multirow[t]{2}{*}{ Module II self-assessment } & 6.0 & 3.18 & 1.55 & 101.81 & \multirow{2}{*}{$\begin{array}{l}U=4945.5 ; Z=-3.577 \\
p<0.000\end{array}$} \\
\hline & 7.0 & 3.95 & 1.36 & 135.71 & \\
\hline \multirow[t]{2}{*}{ Creative attitude } & 6.0 & 7.65 & 2.18 & 98.88 & \multirow{2}{*}{$\begin{array}{l}U=4705.5 ; Z=-4.008 \\
\mathbf{p}<\mathbf{0 . 0 0 0}\end{array}$} \\
\hline & 7.0 & 8.97 & 1.91 & 137.15 & \\
\hline
\end{tabular}

Source: own study

All the results in the sub-scales were statistically significant, which shows differences between the seven- and six-year-old boys. What is symptomatic is that the divergence level is higher in the boys who are a year younger, in other words, the inclination to look for unconventional solutions is lost with age. Obviously, such a hypothesis would need much more extensive studies than those presented in our contribution; however, the tendency is worth further exploration. Other sub-scales, including motivation and self-estimation components showed results pointing to the advantage of the seven-year-olds. Eventually, the overall attitude measure places the older group higher, also with statistical significance. This seems to confirm the results obtained by the girls. Again, it may be concluded that the 
specific lower resistance of the younger boys may remarkably impair complete actualization of their divergence potential in school environment.

Collective analysis was next made for the variables of sex and age: 6-year-old girls, 7-year-old girls and 6-year-old boys, and 7-year-old boys. In all the subscales, the results were statistically significant, which means that at least one group differed from the other ones. The results are presented in Table 4.

Let us analyse individual sub-scales shown in the table below.

- In the case of divergence, the highest average scores were obtained by the 6-year-old boys (Mrank=289), while the lowest values were scored by the girls of the same age $(\mathrm{Mrank}=214)$. The seven-year-old girls and their peers (boys) scored similar average values of about (Mrank $=240)$. We may suggest that the six-year-old boys focus on selecting strategies based on original solutions far more than the girls of the same age as boys who are a year older. A six-year-old is ready to take an effort of seeking his own, original solution and avoids any algorithms, finding them uninteresting.

Table 4. Evaluation of differences among four groups by individual scales

\begin{tabular}{|c|c|c|c|c|c|}
\hline Rating scale & Group & $\mathbf{M}$ & $\mathrm{SD}$ & Average rank & $\mathrm{p}^{*}$ \\
\hline \multirow[t]{4}{*}{ Module 1 divergence aspect } & girls -6 years old & 1.39 & 1.02 & 214.47 & \multirow[t]{4}{*}{0.005} \\
\hline & girls -7 years old & 1.61 & 1.05 & 240.71 & \\
\hline & boys -6 years old & 2.07 & 1.36 & 289.86 & \\
\hline & boys -7 years old & 1.60 & 0.95 & 242.27 & \\
\hline \multirow[t]{4}{*}{ Module 1 motivation aspect } & girls -6 years old & 2.04 & 0.96 & 272.16 & \multirow[t]{4}{*}{0.000} \\
\hline & girls -7 years old & 1.86 & 0.85 & 250.19 & \\
\hline & boys -6 years old & 1.49 & 0.91 & 189.46 & \\
\hline & boys -7 years old & 1.92 & 0.73 & 256.55 & \\
\hline \multirow{4}{*}{$\begin{array}{l}\text { Module } 1 \\
\text { identification }\end{array}$} & girls -6 years old & 4.66 & 1.68 & 225.7 & \multirow[t]{4}{*}{0.005} \\
\hline & girls -7 years old & 5.07 & 1.56 & 264.68 & \\
\hline & boys -6 years old & 4.46 & 1.28 & 204.18 & \\
\hline & boys -7 years old & 5.02 & 1.28 & 255.32 & \\
\hline \multirow{4}{*}{$\begin{array}{l}\text { Module II } \\
\text { interpersonal aspect }\end{array}$} & girls -6 years old & 2.37 & 1.17 & 229.95 & \multirow[t]{4}{*}{0.000} \\
\hline & girls -7 years old & 2.78 & 1.02 & 278.74 & \\
\hline & boys -6 years old & 1.99 & 1.14 & 181.97 & \\
\hline & boys -7 years old & 2.56 & 1.06 & 250.17 & \\
\hline
\end{tabular}




\begin{tabular}{lccccc}
\hline \multicolumn{1}{c}{ Rating scale } & Group & M & SD & Average rank & p $^{*}$ \\
\hline $\begin{array}{l}\text { Module II } \\
\text { intra-personal aspect }\end{array}$ & girls - 6 years old & 1.16 & 0.74 & 215.35 & 0.009 \\
\cline { 2 - 5 } & girls - 7 years old & 1.43 & 0.79 & 263.58 & \\
\cline { 2 - 5 } & boys - 6 years old & 1.15 & 0.80 & 217.46 & \\
\cline { 2 - 5 } & boys - 7 years old & 1.37 & 0.76 & 254.49 & \\
\hline $\begin{array}{l}\text { Module II } \\
\text { self-assessment }\end{array}$ & girls - 6 years old & 3.64 & 1.53 & 218.94 & \multirow{2}{*}{0.000} \\
\cline { 2 - 5 } & girls - 7 years old & 4.30 & 1.31 & 282.70 & \\
\cline { 2 - 5 } & boys - 6 years old & 3.18 & 1.54 & 184.51 & \\
\cline { 2 - 5 } & boys - 7 years old & 3.95 & 1.36 & 249.83 & \\
\hline Creative attitude & girls - 6 years old & 8.30 & 2.57 & 225.74 & \multirow{2}{*}{0.000} \\
\cline { 2 - 5 } & girls - 7 years old & 9.37 & 2.18 & 279.83 & \\
\cline { 2 - 5 } & boys - 6 years old & 7.65 & 2.19 & 180.02 & \\
\cline { 2 - 4 } & boys - 7 years old & 8.97 & 1.91 & 251.91 & \\
\hline
\end{tabular}

Source: own study *based on Kruskal-Wallis test

- The highest motivation level is observed in the 6-year-old girls (Mrank=272), while the lowest one in the 6-year-old boys (Mrank=189). This indicates that girls make use of their potential mostly for others (selecting creative tasks to please the audience of such performance), manifesting even some "community commitment" traits. We would even claim that they tend to shock their environment, to astonish and to be recognized; therefore their performance avoids any accepted rules. They are not afraid of astonishing others as they have a well-established awareness of their own merits. Boys, on the other hand, look for some well-proved solutions to ensure success. They want to be accepted and this is why they submit.

In this category, the average scores were similar for the whole group of seven-year-olds, about (Mrank=250), which points to counterbalancing of adaptive inclinations but also to the presence of nonconformist behaviours.

- The highest level throughout the identification level was achieved by the 7 -year-old girls (Mrank=265), while the lowest by the 6-year-old boys (Mrank=204). Similarly, in self-assessment module II, the highest average values were scored by the 7 -year-old girls $(\mathrm{Mrank}=283)$, and the lowest ones by the 6-year-old boys. This proves the ability of self-reliant coping with difficult tasks among seven-year-olds, regardless of opinions expressed by others. They show little interest in their friends' opinions and are not afraid of being ridiculed. Nevertheless, they are able to understand those 
who failed (empathic traits). Seven-year-old girls show more interest when facing a difficult task, which they find challenging and where they can prove themselves. Therefore, they look for even more opportunities to improve and do not hesitate to face most of the challenges.

- Taken globally, the creative attitude reaches the highest level among the 7 -year-old girls $(\mathrm{Mrank}=280)$, and the lowest in the 6-year-old boys (Mrank=180).

Interestingly, there is a regularity of advantage of the seven-year-old girls, who are likely to turn the earliest to mature targeted choices of creative strategies. They show stronger motivation to perform in an original way, caring about their image of an outstanding, nonconformist individual.

Finally, we compared the evaluated children, abandoning the dimorphic division, to leave only the variable of age (Table 5).

The most important observation is that in the sub-scales of divergence and motivation, both the six- and seven-year-olds obtained very similar results (with well-balanced scores in the girls and boys). In the identification scale, the seven-year-olds obtained higher scores $($ Mrank=260.03) than the six-year-olds (Mrank=214.39). The older children scored higher values also in the interpersonal and intra-personal scales and globally, throughout the self-assessment module. Eventually, this proved true also for the overall measure of creative attitudes. In all the scales, the results proved statistically significant at $\mathrm{p}<0.001$, which points to age as a significant differentiating factor in the tested group.

Table 5. SPTO results by age $(\mathrm{N}=490)$

\begin{tabular}{|c|c|c|c|c|c|}
\hline \multirow{2}{*}{ Rating scale } & \multirow{2}{*}{ Age } & \multirow{2}{*}{ M } & \multirow{2}{*}{ SD } & \multicolumn{2}{|c|}{ U-Mann Whitney test } \\
\hline & & & & Average rank & Test parameters \\
\hline \multirow{2}{*}{$\begin{array}{l}\text { Module I } \\
\text { divergence }\end{array}$} & 6.0 & 1.75 & 1.25 & 254.10 & \multirow{2}{*}{$\begin{array}{l}U=24711,000 ; Z=-, 961 ; \\
p<0,337\end{array}$} \\
\hline & 7.0 & 1.61 & 1.01 & 241.49 & \\
\hline \multirow{2}{*}{$\begin{array}{l}\text { Module I } \\
\text { motivation aspect }\end{array}$} & 6.0 & 1.75 & 0.97 & 228.69 & \multirow{2}{*}{$\begin{array}{l}U=23429,500 ; Z=-1,952 \\
p<0,051\end{array}$} \\
\hline & 7.0 & 1.89 & 0.79 & 253.35 & \\
\hline \multirow{2}{*}{$\begin{array}{l}\text { Module I } \\
\text { identification }\end{array}$} & 6.0 & 4.56 & 1.48 & 214.39 & \multirow{2}{*}{$\begin{array}{l}U=21199,000 ; Z=-3,410 \\
p<0,001\end{array}$} \\
\hline & 7.0 & 5.04 & 1.42 & 260.03 & \\
\hline \multirow{2}{*}{$\begin{array}{l}\text { Module II } \\
\text { interpersonal aspect }\end{array}$} & 6.0 & 2.17 & 1.16 & 204.73 & \multirow{2}{*}{$\begin{array}{l}U=19692,000 ; Z=-4,515 \\
p<0,000\end{array}$} \\
\hline & 7.0 & 2.67 & 1.05 & 264.54 & \\
\hline \multirow{2}{*}{$\begin{array}{l}\text { Module II } \\
\text { intra-personal aspect }\end{array}$} & 6.0 & 1.15 & 0.77 & 216.46 & \multirow{2}{*}{$\begin{array}{l}U=21522,000 ; Z=-3,356 \\
p<0,001\end{array}$} \\
\hline & 7.0 & 1.40 & 0.77 & 259.06 & \\
\hline
\end{tabular}




\begin{tabular}{|c|c|c|c|c|c|}
\hline \multirow{2}{*}{ Rating scale } & \multirow{2}{*}{ Age } & \multirow{2}{*}{ M } & \multirow{2}{*}{ SD } & \multicolumn{2}{|c|}{ U-Mann Whitney test } \\
\hline & & & & Average rank & Test parameters \\
\hline \multirow{2}{*}{$\begin{array}{l}\text { Module II } \\
\text { self-assessment }\end{array}$} & 6.0 & 3.40 & 1.55 & 200.84 & \multirow{2}{*}{$\begin{array}{l}U=19085,000 ; Z=-4,878 \\
p<0,000\end{array}$} \\
\hline & 7.0 & 4.13 & 1.35 & 266.36 & \\
\hline \multirow[t]{2}{*}{ Creative Attitude } & 6.0 & 7.95 & 2.39 & 201.71 & \multirow{2}{*}{$\begin{array}{l}U=19221,000 ; Z=-4,729 \\
p<0,000\end{array}$} \\
\hline & 7.0 & 9.17 & 2.05 & 265.95 & \\
\hline
\end{tabular}

Source: own study.

\section{Conclusions}

The obtained results seem to reveal a remarkable difference in the levels of creative attitude among the six- and seven-year-olds. Therefore, the concept of earlier beginning of school attendance by younger children is worth reassessing. This, however, is not the major issue. It appears most dangerous to combine within one form those who have not turned seven yet and to create "inequality," which may have an effect, at least among some children who were implemented into the school schemes too soon, of certain learning difficulties based not on their intellectual development but rather on emotional immaturity. It is necessary to compare again the measures of creative attitudes of six-year-olds completing their pre-school education and six-year-olds placed in form 1 (which will be the subject of our next elaboration). Only then will it be possible to justify ultimately the sense of the lowered school threshold.

There is no need to convince anybody of the importance of the opportunity to actualize the creative potential of a child, showing his/her genuine creative inclinations. It is a regrettable that such arguments do not persuade the decision-makers, who recognize only the benefits of their actions. But it is only a creative child whom a creative potential will give a chance to participate actively in the educational process, preparing him/her to turn in future into a transformable intellectual - an individual ready to change him/herself and his/her environment and ready to inspire others to take new, unobvious ways to arrange the given reality, courageous and open to express his/her own, subjective standpoint.

\section{References}

Bauman Z., (2007), Tożsamość. Rozmowy z Genetto Vecchim, [Identity. Talks with Genetto Vecchin], tłum. J. Łaszcz, GWP, Gdańsk 
Bernacka R.E., (2004), Konformizm i nonkonformizm a twórczość [Conformism, nonconformism and creativity], Wydawnictwo Uniwersytetu Marii Curie-Skłodowskiej, Lublin

Gloton R., Clero C., (1985), Twórcza aktywność dziecka [Creative activity of the child], Wydawnictwa Szkolne i Pedagogiczne, Warszawa.

Golka M., (2008), Socjologia sztuki [Sociology of Art], Centrum Doradztwa i Informacji Difin, Warszawa.

Krasoń K., (2011), Skala Postaw Twórczych i Odtwórczych (SPTO). Podręcznik testu - wersja dla uczniów szkoły podstawowej klas I-III [A scale of creative and imitative attitude (SPTO) A manual of test - version for elementary school pupils of years 1-3], Ministerstwo Edukacji Narodowej, Kraków.

Kubicka D., (2003), Twórcze działanie dziecka w sytuacji zabawowo-zadaniowej, [A Creative work of a child in a task-play situation, Wydawnictwo Uniwersytetu Jagiellońskiego, Kraków.

Kubicka D., (2005), Strategie i techniki badania twórczości, [w:] W poszukiwaniu zastosowań psychologii twórczości [Strategies and techniques of creativity investigation in: In search of psychology of creativity implementation], red. A. Tokarz, Wydawnictwo Uniwersytetu Jagiellońskiego, Kraków.

Nęcka E., (2001), Psychologia twórczości [Psychology of creativity], Gdańskie Wydawnictwo Psychologiczne, Gdańsk.

Śliwerski B., (2009), Współczesna myśl pedagogiczna [Contemporary pedagogical thought], Oficyna Wydawnicza "Impuls” Kraków.

Trojanowska-Kaczmarska A., (1971), Dziecko i twórczość [A child and creativity], Ossolineum, Wrocław.

Wojciszke B., (2002), Człowiek wśród ludzi [A human being among people], Scholar, Warszawa.

Zborowski J., (1986), Rozwijanie aktywności twórczej dzieci [Development of children's creative activity], Wydawnictwa Szkolne i Pedagogiczne, Warszawa. 

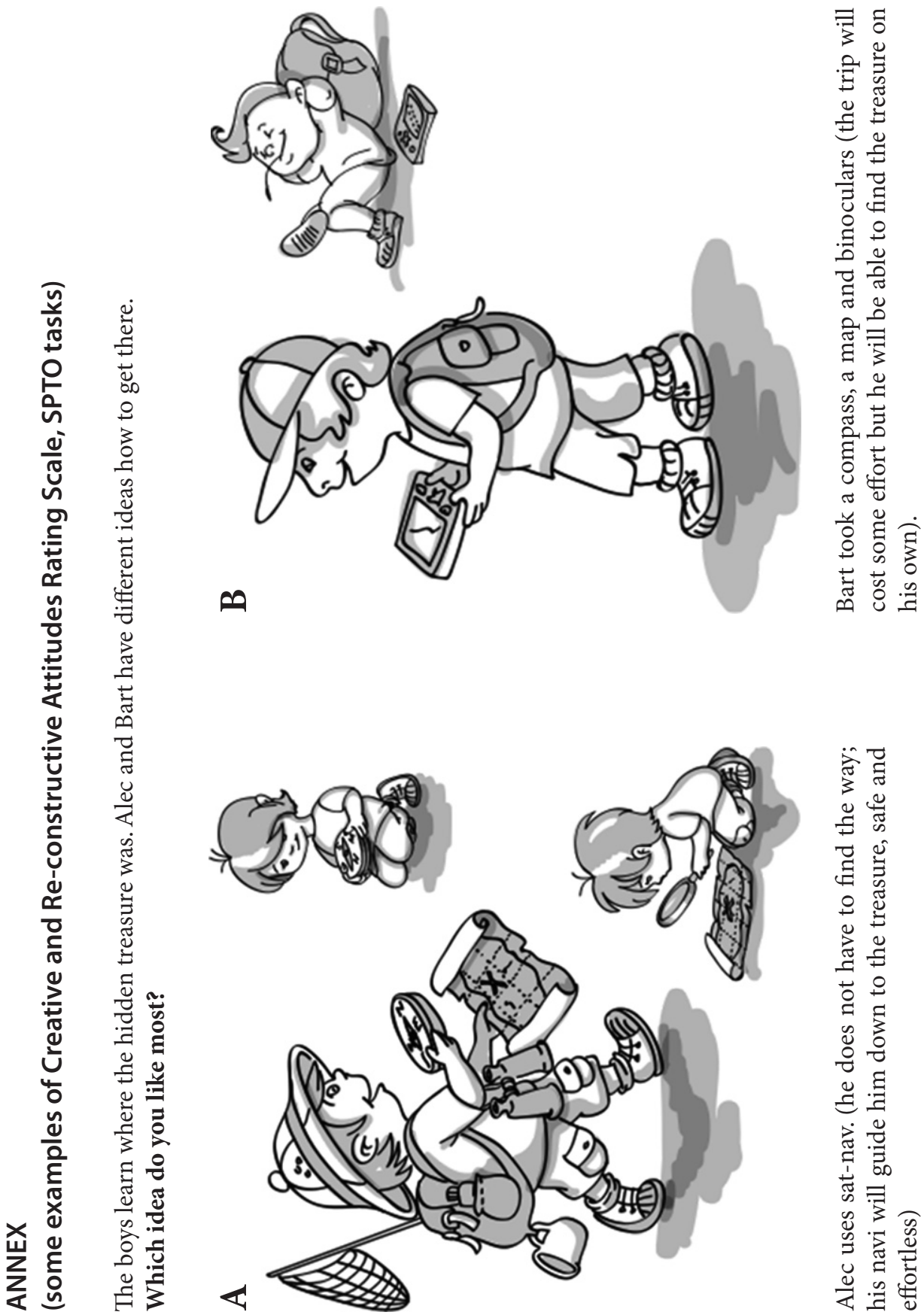

๓
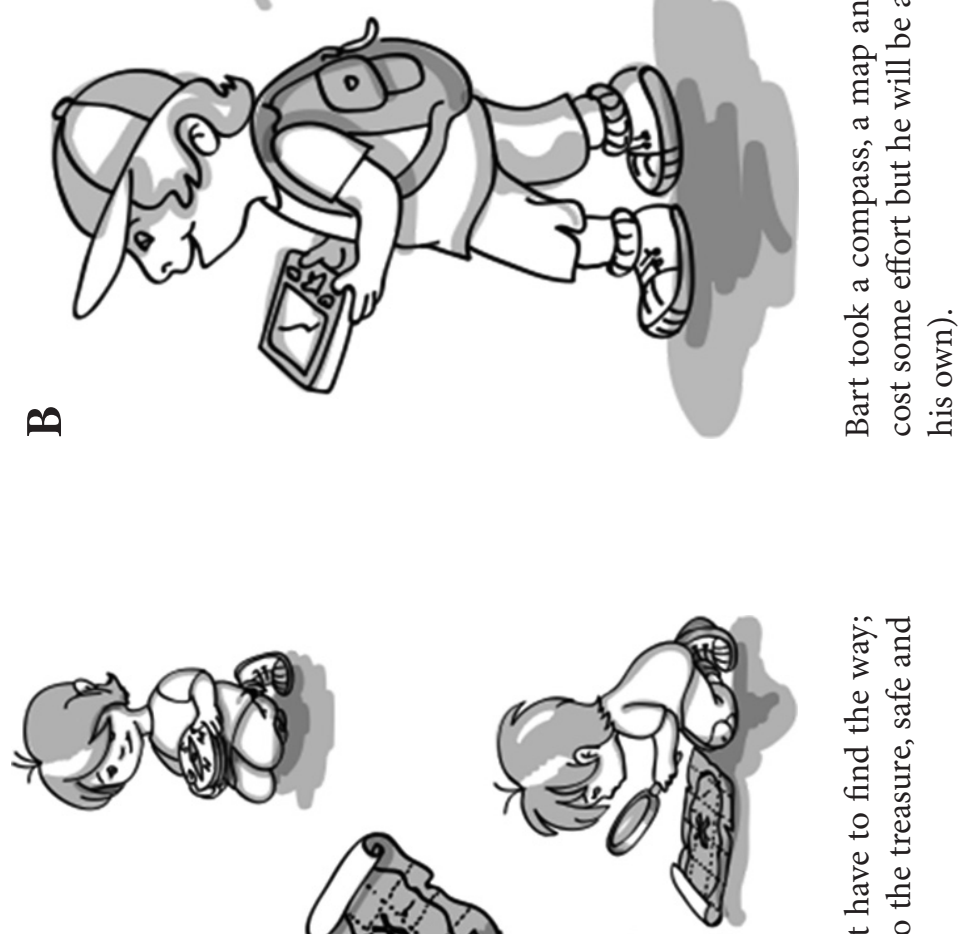

ᄎ듈

壱

렬

원

空

$+0$

ఖे

¿.

突苛

莕

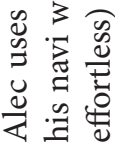




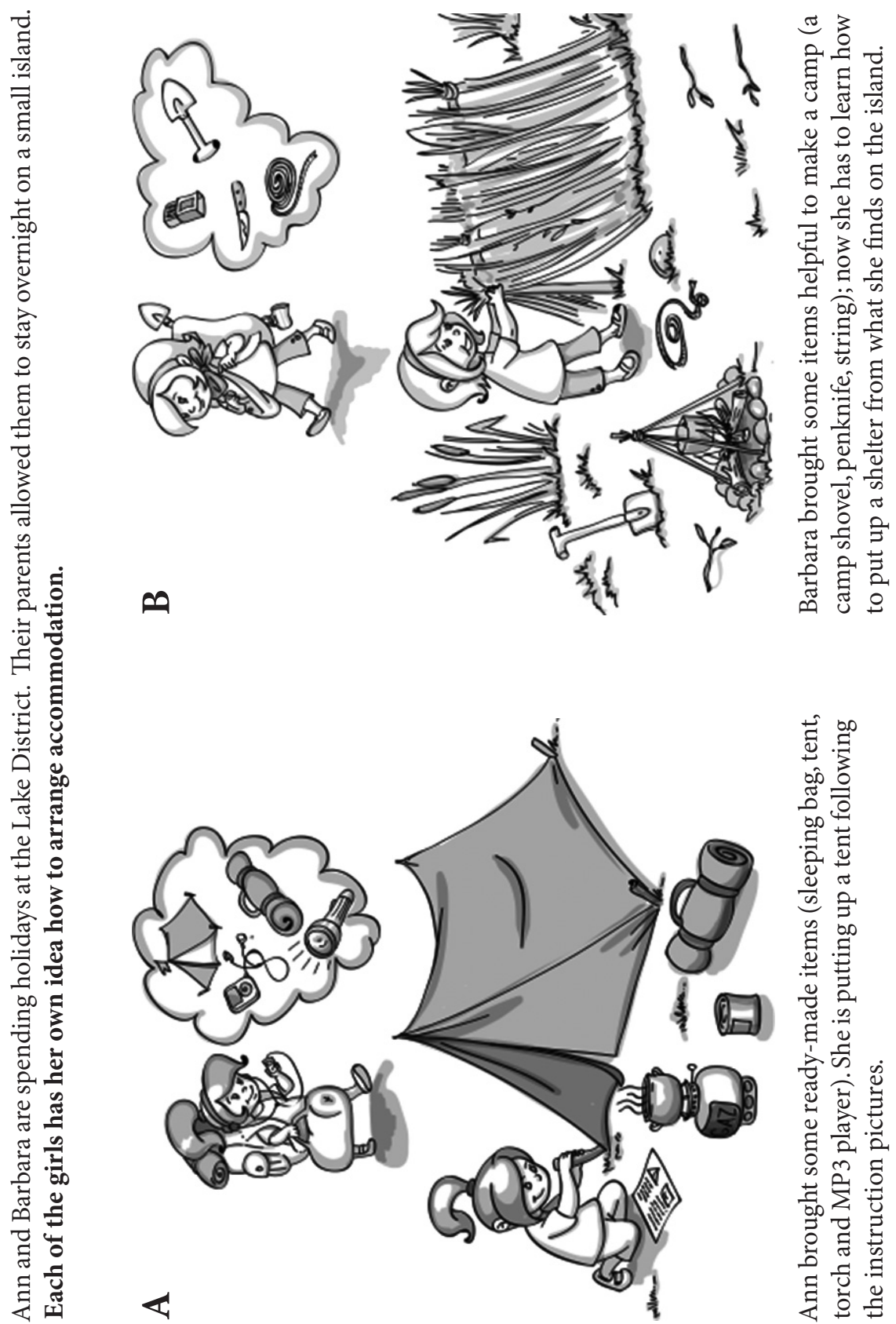

